\title{
Research: A Pathway Towards a Good Curriculum Vitae
}

\author{
Muhammad T. Shakoor', Samia Ayub², Zunaira Ayubs³.
}

\begin{abstract}
The Experience.
Nowadays there is a lashing trend of doing fellowships. Residency and fellowship positions have become very competitive. From my experience, I found that the majority of candidates who aspire to apply for residency or fellowship positions don't have any significant research backgrounds. Being a medical student myself, I should not blame any other student for this deficiency, as most of the medical schools don't provide basic atmosphere, guidance and infrastructure for undergraduate research activities. By the time students graduate and apply for a residency spot or fellowship position after residency, they have no research credentials with them other than their degree requirements and a few certificates for extracurricular activities. One should realize that these accomplishments merely provide a skeleton for your Curriculum vitae (CV) in order to add depth to your CV you have to be able to include research experiences (that you have acquired during your undergraduate degree), as well as good recommendation letters and advanced clinical experience.' Research work in your $\mathrm{CV}$ will help set you apart. When you go for a job interview, having a strong research background and independent work gives you something to talk about that the interviewer will be interested in. As a student, any efforts in the field of research are highly appreciated. Above all, research training will make you a better-equipped physician with a sharper mind and stronger critical thinking skills.
\end{abstract}

About the Author Muhammad Tariq Shakoor is Internal Medicine resident physician at St Mary Mercy Hospital, Michigan and official reviewer of JAMA, $B M J$, student BMJ, LSJM and JEMSA.
When you put your research work on your CV, it should be something appealing. If you tell them that you have done some statistical analysis work, some repetition of the published work or some substandard work as part of your community medicine posting, there are high chances that your CV may not appeal to the interviewer.

Most medical students think that research is for postgraduate students and research fellows only. Please, don't think you aren't smart enough to get involved. What you may lack is experience, but not intelligence. I have no doubts that every medical student is qualified enough to do independent research. Moreover, you can attain admission to a MS (Master of Science) program to develop research experience and participate in publications, though this may be an over expensive business. The total expenditure for a semester for MS in US can vary from $\$ 6,500$ to $\$ 20,000$. ${ }^{2}$ However, a good MS degree from a reputed university in UK can get you around $£ 5,400$ to $£ 7200$ per annum. ${ }^{3}$

Now the question is how to get started? I have few answers and suggestions to it and hope that it might help the beginners if not everyone. For the convenience of students I have put all this in answer question pattern.

\section{Q. Will it affect my studies?}

A large part of medical student community thinks that it can affect our studies but ideally speaking, not much. You are all smart enough to maintain a balance between the two. Especially, at first you'll probably find out that doing research is not so easy; expect it to be challenging. You will find out very early on where your true strengths and weaknesses lie. You are going to find out how motivated you are to be successful. If you remain committed, you are going to learn to solve your own problems and you are really going to find out what it means to be a lifelong learner.

\section{Q. Should I start with Independent studies?}

Without a doubt, I would like to see every student electing to do an independent research study. I strongly encourage every student who has not yet done so to make a genuine and full commitment to work with at least one of your graduate school faculty members. I recommend you do your initial work with a "CAPE" mentor (Capable, Available, Project interests you, Easy to get along with) because you will get plenty of support from him. ${ }^{4}$ You may need it, especially when you start out, but with time you will learn how satisfying it is to be independent.

\section{Q. How do I find a mentor?}

The answer is, when you have narrowed your interests down to one or more broad areas (specialties), you can seek advice when choosing a mentor, and also ask for suggestions on which labs would be good for short-term students. Talk to the faculty. Don't be shy; every faculty 
member would love to talk with you about his or her own research interests. You might start with your course directors and lecturers, if their expertise is in one of your areas of interest. You can also e-mail or make appointments with the relevant Department Chairs or Division Chiefs, Directors of Centers or Institutes, and Graduate Group Chairs or track chairs. Some of these folks will be extremely busy, and you may have to be persistent. Don't give up after one e-mail if you don't hear from someone. You should also get the advice of your fellow students, senior students who have already been through this process. Once you have a list of particular labs that you are interested in, contact those faculty members directly, perhaps by e-mail. Tell them about your enthusiasm for their research and ask if they would be interested in having a medical student in the lab. If so request a chance to meet with them to discuss possible projects. If not, perhaps ask if there are others they would recommend.

\section{Q. Should I do research in a competitive field?}

The answer here is to do substantive research that you are interested. The key is to find something you are passionate about. Find out what is going on in your major area or even in areas outside of your majors. Talk to the other students who are or have done independent study projects. Identify a topic that seems interesting to you. Don't think you have to immediately come up with your own original ideas for a project. There are plenty of good project ideas that you can develop as you gain experience. If you do have your own idea, that is great too.

\section{Q. What are the research opportunities available for under- graduates?}

Another factor that bothers some of the students is Research Opportunities at Undergraduate level. By the way, there are various opportunities; the only thing you should know is how to tap them. For example, there are a lot of institutions that sponsor Medical Student Summer Fellowship Program, an eight-week research program offered to medical students. ${ }^{5}$ This is just one example but these opportunities may vary from country to country and institution to institution. No one can find them for you; it is you who has to find them. You can ask other students who are doing research work or you can ask the faculty members.

\section{Q. How could Medical Schools help their students?}

Well I have a suggestion here; "Research Cells" should be integral part of every Medical Institution to promote research methodology awareness in medical students by frequent arrangements of research workshops, seminars and arranging research competitions. Because this is always the first step that looks impossible, so institutions are supposed to help their students in their first step. There should be a requirement in curriculum that should obligate students to do independent study or research. Students should be included as co-authors. Monetary compensation for work must also be rendered, as it would be if the assistant was a non-student. Every medical school should open paid research spots especially in summer vacations that will work as an incentive.

For those who have not yet initiated independent research projects, please seriously consider doing so. If you have already done independent research and have found it to be one of your best college experiences, congratulations to you! If you did an independent project, and it was not fully satisfying, try again, perhaps with another mentor.

More importantly, I really do hope that you will discover for yourselves what I have discovered for myself that doing independent research was absolutely the very best educational experience of my entire college career. Please, get started as soon as you can.

\section{References.}

1. The University of Vermont College of Medicine Career Services. Build a Resume. April 13, 2012. http://www.uvm.edu/ career/?Page=resume. html¿tSM=jobsubmenu.html

2. USA Study Guide. Study in America: Colleges and Universities in the USA. www.usastudyguide.com April 10,2012

3. Study Abroad Universities. Cost of studying in UK. www. studyabroaduniversities.com April 10, 2012

4. American College of Physicians. How medical students should spend their final free summer. http://blog.acphospitalist.org. Friday, February 24, 2012

5. American Association of Neurological Surgeons. AANS Medical Student Summer Research Fellowship. http://www.aans.org/Grants\%20 and\%20Fellowships/Medical\%20Students\%20Summer\%20Research\%20 Opportunities.aspx February 25, 2012 